\title{
ASSESSMENT OF CORN WATER UPTAKE BASED ON SAP HEAT TRACING UNDER WATER-STRESSED CONDITIONS ${ }^{1}$
}

\author{
Antonio Odair Santos ${ }^{2}$, Homero Bergamaschi ${ }^{3}$ Luís M. G. Rosa ${ }^{3}$, João I. Bergonci \\ \& Bernadete Radin ${ }^{4}$
}

\begin{abstract}
Crop water monitoring is an important aspect for precise control of irrigation. A reliable and movable technique is needed to properly assess water uptake of crops in the field. Water uptake by field grown maize (Zea mays L.), in water-limited conditions was verified with the heat pulse system. The temperature difference between two radially inserted thermocouples, one $9 \mathrm{~mm}$ above and the other $4 \mathrm{~mm}$ below a heater piercing the maize stem, was measured every $0.3 \mathrm{sec}$ following emission of a heat pulse in conditions of varied atmospheric demand. Comparisons of heat pulse system outputs and a high precision transpiration model estimates were done on hourly and daily basis, when low sap velocities were expected to occur. Hourly and daily basis of the heat pulse outputs and model estimates were in agreement. Sensitiveness of the technique was observed even for very low sap velocities.
\end{abstract}

Key words: sap flow, transpiration, water stress, heat pulse

\section{AVALIAÇÃO DE ABSORÇÃO DE ÁGUA BASEADA NA TÉCNICA DO PULSO DE CALOR SOB CONDIÇÕES DE ESTRESSE HÍDRICO}

\begin{abstract}
RESUMO
O monitoramento das necessidades hídricas é um aspecto importante para o controle preciso da irrigação. Técnicas portáteis e de boa confiabilidade se fazem necessárias para a correta determinação do consumo hídrico das culturas em campo. A absorção de água pela cultura do milho (Zea mays L.), cultivada, em condições de limitação hídrica no solo, foi verificada através da técnica do pulso de calor. Após a emissão de um pulso de calor, procedeu-se a medições, a cada $0,3 \mathrm{seg}$, do diferencial de temperatura entre dois termopares, inseridos radialmente no caule da planta. O primeiro foi colocado $9 \mathrm{~mm}$ acima e o segundo $4 \mathrm{~mm}$ abaixo de uma fonte de calor ("heater"). Foram feitas comparações entre as medições pela técnica do pulso de calor e estimativas da transpiração computadas por um modelo de alta precisão, numa base horária e diária. Medições pelo pulso de calor e as estimativas pelo modelo apresentaram concordância, tanto para valores horários como diários. Foi constatado sensibilidade da técnica, mesmo para valores muito baixos de velocidade da seiva.
\end{abstract}

Palavras-chave: fluxo de seiva, transpiração, estresse hídrico, pulso de calor

\footnotetext{
${ }^{1}$ Research funded by the Universidade Federal do Rio Grande do Sul, University of Kassel (Germany) and Brazilian Council for Scientific and Technological Development (CNPq)

${ }^{2}$ Eng $^{\circ}$.Agr ${ }^{\circ}$., Dr, Pesquisador do Instituto Agronômico (IAC). Av. Barão de Itapura, 1481, CP 28. CEP 13001 - 970 , Campinas, SP, E-mail: odairsan@barao.iac.br

${ }^{3}$ Professor Dr. do Departamento de Plantas Forrageiras e Agrometeorologia da Universidade Federal do Rio Grande do Sul. Av. Bento Gonçalves, 7712, CP 776, CEP 91501 - 970, Porto Alegre, RS

${ }^{4}$ Enga ${ }^{a}$. Agra ., M.Sc. Pós-graduanda - Universidade Federal do Rio Grande do Sul
} 


\section{INTRODUCTION}

There is a need for a rapid, simple, movable and reliable method for measuring water uptake of herbaceous plants in order to properly monitor the water usage and establish plantwater relationships of agricultural crops with the main purpose of precise irrigation management.

The assessment of rate of water uptake from measurements of the rate of sap flow through the stem, for some herbaceous plants and trees have been made by the heat pulse system. The technique was first studied by Huber \& Schmidt (1937) and is based on heat as a tracer to detect the xylem sap movement, using implanted sensors. There have been efforts to develop and calibrate the system for various species of agricultural crops such as cotton (Cohen et al., 1988) and maize (Santos et al., 1998), among others, due to the feasibility of the technique for monitoring field crop water needs.

Santos et al. (1997 and 1998) discussed the heat pulse application to a maize crop under well-watered conditions, and pointed out correlation between lysimetric and heat pulse measurement.

For decreasing soil water content, however, Kramer \& Boyer (1995) showed that a more pronounced lag of absorption behind transpiration can be present. This could cause discrepancy between the heat pulse velocity and rate of transpiration all over the day. Thus, it is not certain that all cross sections of the stem are involved in water conduction at the same velocity. Therefore, further investigation of the technique under conditions of decreased soil water content is needed.

The aim of this study is to investigate the water uptake of field grown maize by applying the heat pulse technique, under condition of water stress. A modified Penman-Monteith energy balance equation for sunlit and shaded canopy water loss estimation (Santos et al., 1999) was used to make comparisons with the data output from heat pulse.

\section{THEORY}

Sap flow determinations using a heat pulse as a tracer are based on heat conduction and convection in a homogeneous and isotropic medium (Swanson \& Whitfield, 1981). For conduction:

$$
\frac{\partial \mathrm{T}}{\partial \mathrm{t}}=\mathrm{k}\left(\frac{\partial^{2} \mathrm{~T}}{\partial \mathrm{x}^{2}}+\frac{\partial^{2} \mathrm{~T}}{\partial \mathrm{y}^{2}}+\frac{\partial^{2} \mathrm{~T}}{\partial \mathrm{z}^{2}}\right)
$$

where $\mathrm{T}$ is the temperature departure from ambient $\left({ }^{\circ} \mathrm{C}\right), \mathrm{t}$ is the time and $\mathrm{k}$ is the thermal diffusivity $\left(\mathrm{m}^{2} \mathrm{~s}^{-1}\right)$.

For convection:

$$
-\operatorname{au} \rho_{\mathrm{s}} \mathrm{C}_{\mathrm{s}} \frac{\partial \mathrm{T}}{\partial \mathrm{x}} \Delta \mathrm{x}
$$

where $\mathrm{a}$ is the sap conducting fractional cross sectional area of stem $\left(\mathrm{m}^{2}\right), \mathrm{u}$ is the velocity $\left(\mathrm{m} \mathrm{s}^{-1}\right), \rho$ and $\mathrm{C}$ are respectively the density $\left(\mathrm{g} \mathrm{m}^{-3}\right)$ and specific heat $\left(\mathrm{J} \mathrm{g}^{-1}{ }^{\circ} \mathrm{C}^{-1}\right)$ of plant sap, $\partial \mathrm{T} / \partial \mathrm{x}$ is the temperature gradient across the stem $\left({ }^{\circ} \mathrm{C} \mathrm{m}^{-1}\right)$ and $\Delta \mathrm{x}$ is the distance between cross sectional area and any plane area perpendicular to the $\mathrm{x}$ axis $(\mathrm{m})$.

For a two-dimensional simplification of a three-dimensional heat flow condition and assuming the linear heater and point temperature sensors are installed radially into the xylem and so, heat conduction and convection in the two direction perpendicular to the heater must be accounted for (Fig. 1), and also if sap flows along the $\mathrm{x}$ direction, we may combine conduction and convection and write for the time variation of temperature (Carslaw \& Jaeger, 1947; Marshall, 1958):

$$
\frac{\partial \mathrm{T}}{\partial \mathrm{t}}=\mathrm{k}_{\mathrm{x}} \frac{\partial^{2} \mathrm{~T}}{\partial \mathrm{x}^{2}}+\mathrm{k}_{\mathrm{y}} \frac{\partial^{2} \mathrm{~T}}{\partial \mathrm{y}^{2}}-\mathrm{au} \frac{\rho_{\mathrm{s}} \mathrm{C}_{\mathrm{s}} \Delta \mathrm{T}}{\rho \mathrm{C} \Delta \mathrm{x}}+\frac{\mathrm{Q}}{\rho \mathrm{C}}
$$

where $\mathrm{k}_{\mathrm{x}}$ and $\mathrm{k}_{\mathrm{y}}$ are the axial and tangential thermal diffusivities $\left(\mathrm{m}^{2} \mathrm{~s}^{-1}\right)$ of the wood-sap mixture, $\rho$ and $\mathrm{C}$ respectively the density $\left(\mathrm{g} \mathrm{m}^{-3}\right)$ and specific heat $\left(\mathrm{J} \mathrm{g} \mathrm{g}^{-1}{ }^{\circ} \mathrm{C}^{-1}\right)$ of wet wood and $\mathrm{Q}$ is the temperature rise due to internally generated heat.

Marshall (1958) defined heat pulse velocity as:

$$
\mathrm{v}=\mathrm{au} \frac{\rho_{\mathrm{s}} \mathrm{C}_{\mathrm{s}}}{\rho \mathrm{C}}
$$

and showed that if $\mathrm{Q}$ represents an instantaneous heat pulse at $\mathrm{x}=\mathrm{y}=\mathrm{t}=0$, the heater and sensors are infinitely small, the xylem is infinitely large, thermally homogenous and isotropic $\left(\mathrm{k}_{\mathrm{x}}=\mathrm{k}_{\mathrm{y}}\right)$ and also the sap stream is uniformly distributed, Eq. (3) may be solved for $\mathrm{T}$ as:

$$
\mathrm{T}=(\mathrm{Q} /(4 \pi \rho \mathrm{Ckt})) \exp \left[-(\mathrm{x}-\mathrm{vt})^{2}+\mathrm{y}^{2} /(4 \mathrm{kt})\right]
$$

with $\mathrm{T}$ being the temperature elevation $\left({ }^{\circ} \mathrm{C}\right)$ produced by the heat pulse after time $\mathrm{t}$ and at a distance $\mathrm{x}(\mathrm{mm})$ directly downstream of the linear heater; $Q$ is the heat output per unit length of the heater $\left(\mathrm{J} \mathrm{mm}^{-1}\right)$; and $\mathrm{v}$ is the convective heat velocity $\left(\mathrm{mm} \mathrm{s}^{-1}\right)$.

Eq. (5) may be manipulated in several ways to extract $v$ from the temperature variation with time at one or more points $(x, y)$ in the xylem.

Placing the line heater and the temperature probe in the same diametrical, longitudinal plane simplifies the solution of Eq. (5) to an apparent one-dimensional form (Santos et al., 1998). The temperature wave reaches its maximum $\mathrm{t}_{\mathrm{m}}$ seconds after emission of a heat pulse. If the derivative of $\mathrm{T}$ with respect to time in $\mathrm{Eq}$. (5) at $\mathrm{t}=\mathrm{t}_{\mathrm{m}}$ is zero, then:

$$
v=\left(x^{2}-4 k t_{m}\right)^{0.5} / t_{m}
$$

Herbaceous plants, such as maize are thermally coupled to environment. Therefore fluctuations in the ambient temperature disturb the temperature evolution described in Eq. (5). The thermal diffusivity of stems is also difficult to evaluate. To overcome these difficulties, Closs (1958) suggested the use of a differential temperature measurement at two asymmetrically located points above and below the heat source. In this case, if the two sensors indicate the same temperature $\left(\mathrm{T}_{1}=\mathrm{T}_{2}\right)$, the convective velocity, $\mathrm{v}$, is given as:

$$
\mathrm{v}=\left(\mathrm{x}_{1}-\mathrm{x}_{2}\right) / 2 \mathrm{t}_{0}
$$

with $\mathrm{x}_{1}$ and $\mathrm{x}_{2}$ being the distances directly above and below the line heat source, respectively, and $t_{0}$ is the time required for the temperature difference between $x_{1}$ and $x_{2}$ to return to its initial value.

The accuracy with which $\mathrm{t}_{\mathrm{m}}$ in Eq. (6) or $\mathrm{t}_{0}$ in Eq. (7) can be 
detected depends on the absolute rate of temperature change as $\mathrm{t}_{\mathrm{m}}$ or $\mathrm{t}_{0}$ is approached.

For cotton, Cohen et al. (1988) have shown that $\mathrm{t}_{\mathrm{m}}$ and $\mathrm{t}_{0}$ detectibility is a function of the sap velocity and probe configuration. The temperature difference curves (downstream minus upstream sensor) have an initial downward swing (Fig. 1), which is more pronounced when the upstream thermometer is closer to the heater. The authors have pointed out an arrangement of $x_{1}=6 \mathrm{~mm}$ and $x_{2}=2 \mathrm{~mm}$ as the closest spacing achievable with heaters and thermometers built using the smallest standard hypodermic needle $(0.55 \mathrm{~mm})$. However, in practice, more reproducible results were possible with sensors placed $4 \mathrm{~mm}$ upstream and $9 \mathrm{~mm}$ downstream of the heater.

Cohen et al. (1988) have shown for cotton, that in the range of sap velocity between 0.17 and $0.22 \mathrm{~mm} \mathrm{~s}^{-1}$ both $\mathrm{t}_{0}$ and $\mathrm{t}_{\mathrm{m}}$ can be measured with reasonable accuracy. Using $t_{0}$ we can determine $\mathrm{v}$ from Eq. (7), and rebuild Eq. (6) to determine $\mathrm{k}$.

Transpiration rate $(\mathrm{Tr})$ calculated with $\mathrm{t}_{0}$ or $\mathrm{t}_{\mathrm{m}}$ can finally be calculated as:

$$
\operatorname{Tr}=v\left(t_{0}, t_{m}\right) \cdot C_{f} \frac{d^{2} \pi}{4}
$$

where $\mathrm{C}_{\mathrm{f}}$ is the calibration factor for the specific herbaceous species and $d$ is the averaged stem diameter where the probe is installed.

\section{MATERIAL AND METHODS}

\section{Location, time and crop}

The study was conducted during the growing seasons of $1995 / 96$ and 1996/97 in a 0.5 ha experimental area of maize (Zea mays L.), hybrid Pioneer, in Eldorado do Sul, RS, south of Brazil $\left(30^{\circ} 05^{\prime} \mathrm{S} 51^{\circ} 39^{\prime} \mathrm{W}, 46 \mathrm{~m}\right)$. The maize was planted in rows of $0.75 \mathrm{~m}$ spacing, at the end of October in both years, in a typical plinthic soil (Melo et al., 1996). Fertilizer application was done according to soil analysis. Manual cultivation was done to control weed infestation. Plant population density was close to 67,000 plants ha-1.

Both the growing seasons were characterized by high values of air temperature and saturation deficit at the time of the field experiment. In addition soil water deficit was also observed at the time of field measurements.

\section{Level of stress}

Water stress was permitted to develop over the two consecutive periods. Averaged maximum values of sunlit water potential were found to be $-1800 \mathrm{kPa}$ around mid-day in the plots. Soil moisture (dry mass fraction of water) at a depth of 45 $\mathrm{cm}$ was averaged at $8.35 \%$.

\section{Environmental measurements}

Global radiation (model LI200SZ, Licor Inc., USA), wind speed (model A100R, Vector Instruments, UK), air temperature and humidity (model HPMP35AC, Vaisala, FIN), and rainfall (model ARG100, Environmental Measurements Ltd., UK) were measured two meters above the soil using an automated meteorological station (model W2000, Campbell Scientific, Logan, USA) installed close to the experimental area.

\section{Instrumentation for heat pulsing}

The probe block for sap monitoring that was installed in the maize stem consisted of a line heating element and two temperature sensors mounted on a fiber plate, 40 by 20 by $8 \mathrm{~mm}$ (Cohen et al., 1988). The heating element was a stainless steel probe of $0.55 \mathrm{~mm}$ (internal diameter) and $65 \mathrm{~mm}$ length. The temperature sensors comprised copper constantan thermocouples, inserted into a section of stainless steel hypodermic needles $(0.55 \mathrm{~mm}$ of internal diameter and $65 \mathrm{~mm}$ length). The needles (temperature sensors and heating element) were inserted into the stem diametrically. Thermocouples were inserted asymmetrically, respectively, 4 and $9 \mathrm{~mm}$ distant from the heater for upstream and downstream sensors. The heating element was wired in both ends to conduct the heating current from a 12 volt car battery. The temperature sensors were connected to a datalogger (Fig. 1).

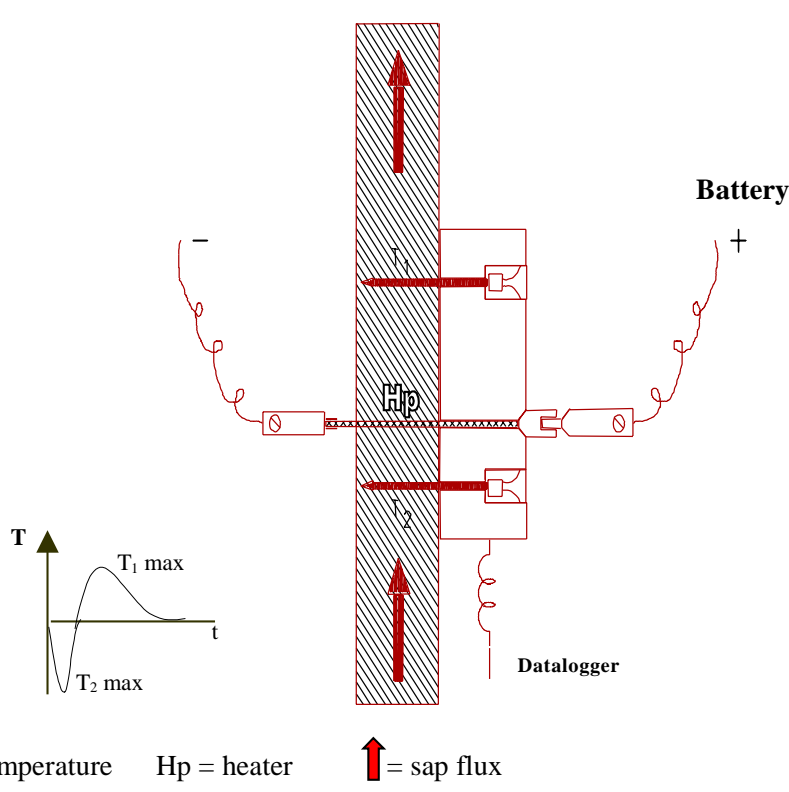

Figure 1. Probe configuration for measurement of heat flux in the stem of maize plant by detecting differential temperature between $T_{1}$ (downstream sensor) and $T_{2}$ (upstream sensor) after a heat pulse emitted by the heater $(\mathrm{Hp})$. Differential curve of temperature are shown

\section{Experimental procedure}

Installation of heat pulse probes was done at the base of 8 maize stem considering representative plants of the full range stem diameters and when maize had full foliage cover of the soil. Prior to installation the stem was "cleaned" of the first husks and measurement of diameter was taken. A heat pulse of $0.3 \mathrm{sec}$ was applied to the stem and the temperature difference between the thermocouples above and below the heater was monitored at $0.3 \mathrm{sec}$ intervals by using a datalogger (CR21X - Campbell Scientific, Logan, UT). After 7 to 10 days the blocks were removed and new plants were chosen in order to avoid stem damage due to over heating. Comparisons of the heat pulse technique outputs were made by using simultaneous estimates performed by a modified Penman-Monteith energy balance equation (P-M model) (Santos et al., 1999). 


\section{RESULTS AND DISCUSSION}

Figure 2A shows diurnal course of measured maize water uptake and estimated transpiration rate under conditions of high atmospheric demand. The evolution of the estimated and measured curves look very similar all along the day and the daily totals obtained are very close. Some discrepancies between estimated and measured values recorded in the early morning and in the late afternoon are due to the accumulation of water in the tissues (capacitance). This phenomenon causes the water flow to be transient (Kramer \& Boyer, 1995) and is not part of the modeling.

A. High atmospheric demands

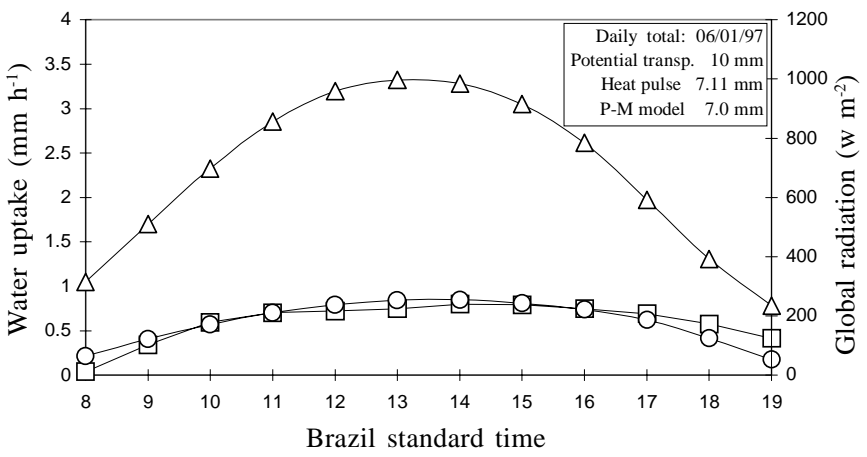

B. Low atmospheric demands

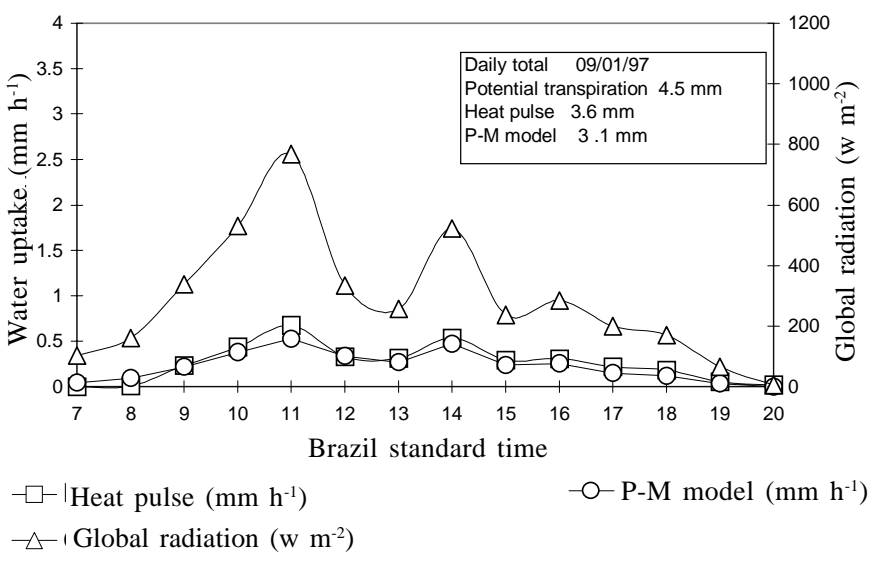

Figure 2. Daily course and daily totals of measured and estimated values of corn water uptake under high (A) and low (B) atmospheric demand and water-stressed condition, in the growing season of 1996 - 1997, in Eldorado do Sul, RS

Comparisons between measured water uptake and estimated transpiration values in this soil water-limited condition were necessary, since no other means of direct measurement was available on stressed plots, and is an indication of heat pulse sensitiveness plus a verification of formal biophysical theory description of canopy water loss against real flux of water in the base of stem

In Figure 2B the heat pulse outputs in a low atmospheric demand condition are presented. In this case of atmospheric sink and soil water availability very low values of sap velocity is expected. Values of $t_{0}$ as high as $250 \mathrm{sec}$ were observed for these days. At low sap velocities the accuracy of $\mathrm{t}_{0}$ determination is limited by the resolution of instrumentation. The lowest division of Celsius scale in this study was $0.01^{\circ} \mathrm{C}$. When transpiration is high the precision of $\mathrm{t}_{0}$ determination will depend on the shortest scanning interval of the datalogger (Cohen \& Fuchs, 1989). In this study a $0.3 \mathrm{sec}$ scanning interval was used. This was considered enough for a correct detection. However for low sap velocities detection the most crucial point is the influence of ambient heat properties over the sap stem, which can cause mixing with the heat coming from the pulsing. This can produce wrong values of $t_{0}$. Prior to a heat pulse, the temperature difference between the two thermocouples is often zero, or at least constant $\left(\mathrm{T}_{1}=\mathrm{T}_{2}\right)$. However when the ambient air around the stem is changing rapidly, which is very common in the early morning and late afternoon, temperature gradients develop along the stem. For low sap velocities the gradient magnitude (drift) may be of the same proportion as the rate at which the temperature difference approaches its initial value. To minimize errors, the rate of temperature change was measured $60 \mathrm{sec}$ prior to each emission of a heat pulse and extrapolated linearly with time, in order to adjust temperature differences. This procedure was a shortcut used to eliminate the influence of the ambient temperature on the heat carried in the stem.

Therefore, the used probe configuration allowed the correct detection of sap movement. Despite the measurement water uptake based on the sap heat tracing being based on idealized heat transport theory e.g. (Swanson \& Whitfield, 1981) which is quite complex, the use of probe configuration and a calibration factor (Cohen et al., 1981; Santos et al., 1998) is a practical alternative to the solution of those formal heat transport equations.

Figure 3 shows hourly values of water uptake and estimated transpiration. The growing season of 95/96 was characterized by extreme weather conditions, when low values of relative humidity and high temperatures were observed at the time of data collection as shown in Figure 3. Under these conditions of very high atmospheric sink associated with low soil water availability, the transient fashion of sap flow (Jones, 1992) was highlighted by the comparison between the measured water uptake and estimated transpiration during the period of observation. Two clear lags were observed in the early morning and late afternoon. For the first case model estimates are higher than heat pulse outputs, due to flux-gradient dependence of the whole system of water transport to start, when loss of water occurs at the leaves. Therefore modeled canopy water loss and measured values at the base of the stem differ. At the end of the afternoon, the tissue water storage is responsible for the heat pulse having higher values than estimated ones. While the model produced very low values, the heat pulse still continues measuring water uptake which is still being stored for rehydration of tissues.

This cycle is very characteristic of aspects of crop water deficit development (Kramer \& Boyer, 1995). The lags, as described by the comparisons presented are responsible for the deficit in the morning, and are more and more pronounced as soil water decreases. The lag in the afternoon is responsible for the tissue water recharge of the crop.

Overestimation by the model, in the hottest hours of the days of measurement, as shown in Figure 3, was due to difficulties of modeling the canopy conductance to the vapor transport, as observed by Santos et al. (1999). 


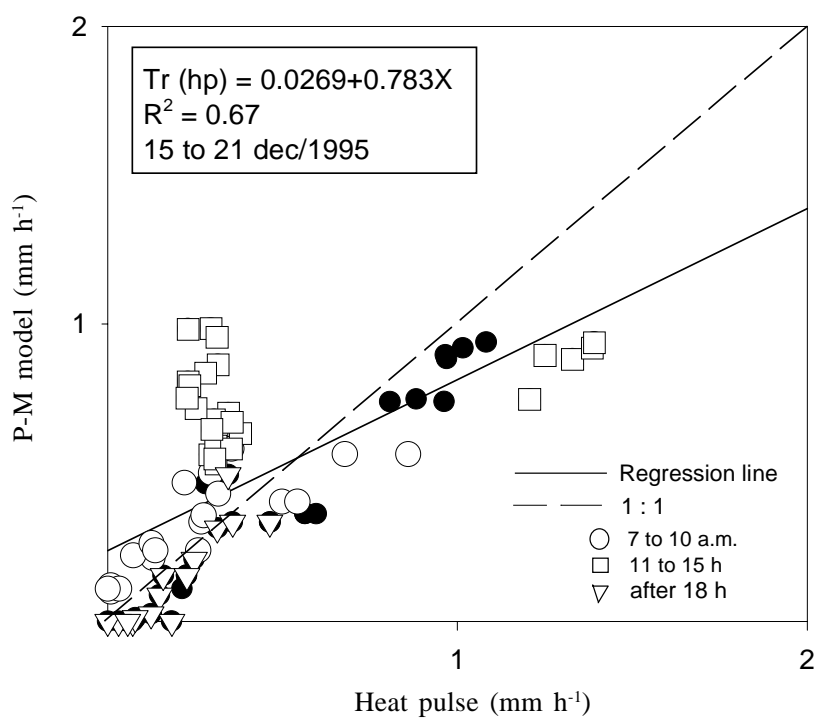

Figure 3. Relationship between measured corn water uptake and estimated canopy water loss values, under water-stressed condition in the growing season of 1995/1996. Regression line and separated values for the diurnal cycle is shown.

\section{CONCLUSIONS}

1. Heat pulse velocity and rate of transpiration, while proportional, were influenced by transient flow of water in the stem .

2. Precision of measurement of maize water uptake under low sap velocities depends on the elimination of ambient temperature influence on the sap flow.

3. For the conditions of water stressed plants, fluctuated atmospheric demand and range of sap velocities found in this work, the water uptake of maize was properly assessed by means the heat pulse technique.

\section{REFERENCES}

CARSLAW, H.S.; JAEGER, J.C. Conduction of heat in solids. Oxford: Clarendon Press, 1947.430p.

CLOSS, R.L. The heat pulse method for measuring rate of sap flow in a plant stem. New Zealand Journal of Science, Wellington, v 1, p.281-288, 1958.
COHEN, Y.; FUCHS, M. Problems in calibrating the heat pulse method for measuring sap flow in the stem of trees and herbaceous plants. Agronomie, Paris, v.9, p.321-325, 1989.

COHEN, Y.; FUCHS, M.; FALKENFLUG V.; MORESHET, S. Calibrated heat pulse method for determining water uptake in cotton. Agronomy Journal, Madison, v.80, p.398-402, 1988.

COHEN, Y.; FUCHS, M.; GREEN, G.C. Improvement of the heat pulse method for determining sap flow in trees. Plant, Cell and Environment, London, v.4, p.391-397, 1981.

HUBER, B.; SCHMIDT, F. Eine Kombinationsmethode zur thermoelektrischen Messung langsamer Saftströme. Gesellschaft Berich, Berlin, v.55, p.385-396, 1937.

JONES, H. G. Plants and microclimate. a quantitative approach to environmental plant physiology. Cambridge: Cambridge University press, $1992.428 \mathrm{p}$.

KRAMER, P. J.; BOYER, J. S. Water relation of plant and soils. Orlando: Academic Press, 1995. 495p.

MARSHALL, D.C. Measurements of sap flow in conifers by heat transport. Plant Physiology, Rockville, v.33, n.6, p.385-396, 1958.

MELO, O.; LEMOS, R.C; ABRAÃO, C. Levantamento dos solos do centro agronômico. Revista da Faculdade de Agronomia e Veterinária da UFRGS, Porto Alegre, v.8, n.114, p 7-155, 1996.

SANTOS, A.O.; BERGAMASCHI, H.; LANGENSIEPEN, M.; BERGONCI, J.I.; ROSA, L.M.G. Verificação do método do pulso de calor para medição direta da transpiração. In: CONGRESSO BRASILEIRODE AGROMETEOROLOGIA, 10, Piracibaca. Anais... Piracicaba: Sociedade Brasileira de Agrometeorologia, 1997. p.722-725.

SANTOS, A.O.; BERGAMASCHI, H.; LANGENSIEPEN, M.; ROSA, L.M.G.; BERGONCI, J.I. Water uptake of field grown maize determined by heat pulse system. Agro-Ciencia, Chillán, Chile. 1998. (in press).

SANTOS, A.O.; BERGAMASCHI, H.; FUCHS, M.; ROSA, L.M.G.; BERGONCI, J.I. Sunlit and shaded maize canopy water loss under varied water stress. Revista Brasileira de Engenharia Agrícola e Ambiental, Campina Grande, 1999. Submitted

SWANSON, R.H.; WHITFIELD, D.W.A. A numerical analysis of heat pulse velocity theory and practice. Journal of Experimental Botany, Oxford, v.32, p.221-239, 1981. 